\title{
Market of fruits and baccas as model of socially oriented market economy in Ukraine
}

\author{
I. Salo, \\ Doctor of Economics \\ Institute of Horticulture, National Academy of Agrarian Sciences of Ukraine
}

The purpose. To open the essence and main routes of socialization of the market of fruits and baccas. Procedure. As the basis for probe they used methodical approaches to determination of capacity of inner consumer market of agricultural products and food. Results. The content of a class «social market of fruits and baccas» from an item of the standard of welfare is opened: solvency of the population and consumption level of products according to rational standards. rincipal causes of instability of economy in Ukraine and inefficiencies of development of the domestic market of fruits and baccas are analyzed. Ways of development of social market, directed at optimal provision of population with fruits and baccas in the long term are offered.

Conclusions. Socially oriented policy and economy of the state should be directed, first of all, on martempering welfare of the population irrespective of its territorial housing. Having selected the domestic market of fruits and baccas as separate model of social market economy and being repelled from the indicator of food provision «sufficiency of consumption of a separate product» it is fixed that the market is only on a path to socialization. Aggregate of the listed directions of the further development of the social market of fruits and baccas and branches of gardening in particular should become an integral part of the Comprehensive programme of development of agrarian market in Ukraine.

Key words: social market, fruits, baccas, consumption, size standard, regulating.

The social aspect of the domestic agricultural market particularly acute in the scientific field is updated during the last two decades. One of the main components in his system is a market of fruits and berries. Therefore, the issue of development of the latter is timely and important, not only on economic efficiency and implementation fruits and berries, but also social, technological and environmental characteristics. It is the totality and interaction these indicators suggest economic growth and the movement of the entire social system.

Study of the formation, operation and development of the domestic market of fruits and berries at different times carried A. Ermakov, T. Markina, V. Rulyev, G. Satina, L. Symyrenko, D.

Chukhno, A. Shestopal, P. Shitt, A. Shumeyko and other scientists. However, their study covers only the period until the Ukraine the status of market economy in $2005 \mathrm{y}$. is therefore virtually unsolved issue in need of attention just in social terms.

Purpose is to detect the essence and main directions of the fruit and small fruit market socialization.

Methods the methodical basis for our research are approaches to determining the volume of the agricultural products and provision internal consumer market [3].

Results. Before you go directly to the market model properties fruits and berries towards a social market economy should reveal the contents of the categories of "social", "socially oriented market economy" and finally "social market fruits and berries."

The category of "social" was first used in his work as a scientific $K$. Marx and defines it as a combination of certain traits and characteristics of public relations $[4,10]$. Other definitions of more advanced verbally, but similar content. They are based is the concept of "public relations". In the literature category of "social" and "public" largely considered identical. For example, under the "social" means a series of various qualities and characteristics of social (public) relations, integrated individuals or communities in the process of joint activities (interaction) in specific circumstances, which are in their relation to each other, to their place in society, the phenomena and processes of social life [5, 6, p. 150]. "Social market economy" is the socioeconomic structure, the economic basis of which is the market. But the latter can not solve many social problems, and therefore resorted to the services of the State [4]. In our opinion, these definitions optimal 
reveal the essence of the above terms, given that they are based on multifaceted social relations (between market operators) and state regulation of economic processes is their result. Socialized market economy is not only aimed at forming an effective market mechanism, but also focused on justice and equality. The framework of government regulation should clearly define and restrict unlike the excessive interference in the market, as in Soviet times.

Thus, the need for urgent government intervention is only where the market mechanism does not work or are significant shortcomings market. British economists Campbell R. McConnell and R. Brue Stanley under "social control" understand the latest and specific type of regulation, when the government is studying the conditions in which goods and services are produced, their physical properties and the impact of their production on society [11]. Thus, social regulation, also weighted, where necessary and reasonable directions takes effect only after study and synthesis of all the features of the market and specific products. S. Mocherny defines the functions of the welfare state with socially oriented market economy [2, p. 419]:

- Equitable distribution of income between different social groups (through the introduction of appropriate taxation);

- Creating conditions for the development of the individual, his abilities;

- The right to meaningful work and human development;

- A high level of material and spiritual needs;

- Social protection of the population from the negative effects of the market economy;

- Ensure economic, social and political stability in society.

In these, in fact, the "rules of socialization", the scientist says that in Ukraine the elements of the welfare state has not yet formed. This is confirmed by developments in the economy and politics of the past three years and the fighting in the east. Another researcher, $\mathrm{V}$. Andreychuk, among the main causes of economic instability in the country highlights the military aggression of the Russian Federation, the devaluation of the national currency, reduction of prices on the world market, particularly for raw materials, the crisis of the banking system of Ukraine, increased inflation and import prices for buying resources, lack of participation in world stock markets, agro-industrial companies with foreign investments and in the occupied areas close to them on sale, etc. [1, p. 13-15].

Based on the fact that everyone has the right to a certain standard of living (the theory of welfare Pareto) distribution of resources should be carried out so as not to have any social situation deteriorated operator socio-economic system. Given this, we believe, under the "social market fruits and berries" means the economic relationships of all its members aimed at ensuring the optimum population these products at least according to the established norms of rational consumption $-82 \mathrm{~kg}$ per person per year. This, in turn, depends primarily on the efficiency of the market and its infrastructure. Currently, the domestic market fruits and berries can not be considered as having optimally.

Among the problems that require urgent attention note key [9]:

- Lack of sufficient areas of industrial plantations;

- Resale products through multiple intermediaries;

- Insufficient development of commodity production of fruits and berries farms and its predominant focus of private households

- average for 2010-2014y. $1.6 \mathrm{mln}$. tons (82.6\%) causes, especially the instability of the offer;

- Underdeveloped infrastructure market, particularly in trade, consumer, insurance, various areas of industrial processing, etc;

- Unfavorable situation - prices for fruit and berries too high for consumers due to insufficient effective demand and low for producers, which leads to a rather small field of horticultural yield $-1.9 \%$ in $2014 \mathrm{y}$;

- Weak economic position in the world market of fruits and berries.

Inefficient functioning of the internal market hampers the development of foreign trade in fruits and berries. Their exports in domestic production on average only $5 \%$.

Based on the determined position of "social market fruits and berries," should reveal features to ensure their population. Consumption of fruits and berries amounted on average in 2010-2014 y. $54.4 \mathrm{~kg}$ per person per year, which is $66.3 \%$ of its normal. Lack needs of the population due, above all, its low purchasing power. 
The problems not structured consumption relative to its rules to other drawback is the uneven distribution of production between segments fruits and berries of the population by income, region, city and country. Richer layers consume 3.5 times more fruit and berries than with lower welfare, namely $70 \mathrm{~kg}$ per person per year. With individual regions, regardless of their membership of a particular area, fruits and berries are exported to other regions and abroad, and developed not only gardening companies, but also households, as evidenced by a low coefficient of correlation between the level of production and consumption of these products

$-\mathrm{R}=(-0.149)-(-0.285)$. This - Vinnytsia, Khmelnytsky, Transcarpathian, Zaporizhia, Kherson and Mykolaiv. A fruits and berries their own software depends largely on the volume of production in the agricultural enterprises $-R=0,478-0,539$. Most fruits exported from Vinnytsia and Khmelnytsky regions and imported in Kiev, where the urban population is dominated by the rural population 6 times. So it is in this region has the highest consumption of fruits and berries $-65 \mathrm{~kg}$ per person per year, while in the urban population -75 , and in agriculture almost 2 times less $-40 \mathrm{~kg}$. This difference is explained by the fact that imported fruits, particularly citrus fruits and bananas consumed mainly urban residents, while rural needs due to lower purchasing power and limited access catered mainly products of own production.

It should also be noted that the consumption of fruits and berries in 2010-2014 y. at 37-40\% dependent on imports. Thus improving provision of population with fruits and berries is possible only if the expansion of industrial production. After all farms takes place in shaping the sustainability of commodity supply dynamics, which makes it a significant increase in this category of households is expected. For further stabilize their production priority is the provision of state social Rural Development under the Law of Ukraine "On the priority of social development of rural and agriculture in the national economy" [7]. In particular, it noted that high levels of socio-economic development of rural areas are essential to ensure food and raw republic, its economic independence, with Art. 5 clearly states that the amount of public investment, which are aimed at strengthening the material-technical base of the social sphere of the village and agriculture, should be at least $1 \%$ of the gross domestic product of Ukraine.

Social domestic market of fruits and berries should evolve in the direction primarily to ensure optimal fruits and berries population, forming the necessary stable commodity supply primarily through domestic production, namely [8, p. 28]: wages should be the main income of rural residents; increase production of high quality fruit and berries in specialized agricultural enterprises, including business partnerships that can ensure healthy competition in the market; parties forming the standard domestic fruits and berries of various range and assortment in required quantities (depending on consumer demand and the potential market infrastructure) to meet both domestic needs and increasing export potential; development of relations between producers and purchasing organizations (intermediaries) must be the basis of the commercial policy of horticultural enterprises and aimed at focusing the main gains in primary care - the direct producers, which is possible with proper structure of trade - wholesale fruit and vegetable markets world standards and cooperation between small producers; pricing in the domestic market of fruits and berries should be aimed at ensuring the affordability of consumption of their products, covering the production costs and the possibility of expanding the offer; the purpose of mutually agreed economic ties between the industry and markets industrial gardening resources should be providing horticultural enterprises with material and technical resources (equipment, fuel, chemicals, fertilizers, etc.) on the principles of equivalence; use in horticultural enterprises ecologically innovative technologies of fruit and berries to maximize profits with minimal production; direction of the development of foreign trade relations with other countries and finding its own niche in the world market; objective is to attract investment capital, including foreign.

With the formation of stable sustainable aimed at eliminating the shadow mechanism entrepreneurial business atmosphere in the country and an effective legal framework provided an opportunity to further the creation of common horticultural enterprises based in part on foreign capital.

\section{Conclusions}

Socially oriented state policies and economy should be aimed primarily at improving the welfare of the population, regardless of its spatial distribution. Highlighted domestic market of fruits and berries as a separate model of social market economy and building on food security indicator «sufficiency of individual 
consumption of the product» established that the market is on the way to socialization. This is evidenced by the low solvency of the population and the consumption of fruits and berries, uneven distribution of products dependence on imports, insufficient development of horticulture industry, the lack of state support, including and major manufacturers fruits and berries - farms, slow development of market infrastructure and so on. The totality of these directions of further development of the social market fruits and berries and horticultural industry in particular should be an integral part of a comprehensive program for the development of agricultural markets in Ukraine.

\section{Bibliography}

1. Andreychuk V.G. Agribusiness Challenge: Finding Answers / V.G. Andreychuk // Economics APC. 2015. - №5. - P. 12-22.

2. Economic Encyclopedia: 3 vol. / [Ed. S.V. Mocherny et al.]. - K., Academy, 2000-2002 y. - T. 3. - 2002. $-952 \mathrm{p}$.

3. The capacity of the domestic consumer market for agricultural products and foodstuffs: monograph / [O. Shpychak, Y. Lupenko, V. Zhuk et al.]; edited by O. Shpychak. - K. NSC IAE, 2013. - 186 p.

4. Eremenko V.G. Social Economy. Second edition, adapted and updated / V.G. Eremenko. - K.: Information-Publishing Center State Statistics Committee, 2003. - $351 \mathrm{p}$.

5. Kuzmenko T. Sociology: teach. manual / T. Kuzmenko. - K: Center of educational literature, 2010. 320 p.

6. Culina A.S. "Public" and "social": problem definition category/ A.S. Culina // Philosophy. Politology. 2005. - №73-75. - P. 149-152.

7. "On the priority of social development of rural areas and agriculture in the national economy" [electronic resource]: Law of Ukraine of 10.17.1990 p. № 400-XII. - Access: http://zakon5.rada.gov.ua/ laws / show / 400-12.

8. Salo I.A. The economic principles of functioning and development of the fruit market in Ukraine: Author. Thesis. for obtaining sciences. the degree of Doctor. Econ. Sciences specials.

08.00.03 "Economics and national economy management" / IA Salo. - K., 2014. - 39 p.

9. Salo I.A. Market development fruits in Ukraine: [monograph]/I.A. Salo. - K. NSC IAE, 2013. - 394 p.

10. Marx K. Capital. Critique of Political Economy / K. Marx. - Berlin-GDR: Ditz Verlag, 1962. - $802 \mathrm{~s}$.

11. McConnell Campbell R. Economics principles, problems, and policies / Campbell R. McConnell, R. Brue Stanley. - New York : McGraw-Hill, 1993. - 906 p. 